\title{
Amended By
}

National Cancer Institute

\section{Source}

National Cancer Institute. Amended By. NCI Thesaurus. Code C73460.

Indicates the person or authoritative body who made an amendment. 